\title{
ANALISIS MODEL PEMBELAJARAN SAINS TEKNOLOGI MASYARAKAT TERHADAP HASIL BELAJAR SISWA PADA MATERI GELOMBANG MEKANIK
}

\author{
Erika Rakhmatika ${ }^{1}$ \\ erikarakhmatika@gmail.com \\ ${ }^{1}$ Pendidikan Fisika Fakultas Keguruan dan Ilmu Pendidikan, Universitas Siliwangi, \\ Tasikmalaya
}

\begin{abstract}
ABSTRAK
Untuk mengetahui penerapan model pembelajaran Sains Teknologi Masyarakat (STM) dengan mengkaji beberapa penelitian yang telah dilakukan terdahulu. Bagian dari ilmu pengetahuan alam (IPA) yang menghasilkan kegiatan manusia berupa pengetahuan, gagasan dan konsep yang teroagnisir tentang alam sekitar yang diperoleh dari pengalaman melalui serangkaian proses ilmiah yaitu merupakan Fisika. Belum maksimalnya proses pembelajaran yang telah dilakukan mengakibatkan rendahnya hasil belajar peserta didik. Oleh karena itu, pentingnya inovasi terhadap model pembelajaran yang dilakukan di kelas, khususnya dalam mata pelajaran fisika. Sains teknologi masyarakat (STM) merupakan salah satu model pembelajaran yang dapat digunakan dalam pembelajaran fisika. Penggunaan model pembelajaran ini dapat digunakan pada materi gelombang mekanik.
\end{abstract}

Kata Kunci: Fisika, Gelombang Mekanik, Sains Teknologi Masyarakat

\section{PENDAHULUAN}

Menurut Kurniawan (2012) pendidikan merupakan kegiatan mengoptimalkan perkembangan potensi, kecakapan, serta karakteristik pribadi peserta didik. Kegiatan pendidikan diarahkan pada pencapaian tujuan pendidikan. Tujuan pendidikan dalam UU RI No 20 Tahun 2003 yang tercantum pada BAB II Pasal 3 Tentang Sistem Pendidikan Nasional menyatakan bahwa Pendidikan nasional berfungsi untuk 
mengembangkan kemampuan, membentuk watak dan peradaban bangsa yang bermartabat dalam rangka mencerdaskan kehidupan bangsa. Selain itu pendidikan bertujuan untuk berkembangnya potensi peserta didik agar menjadi manusia yang beriman dan bertakwa kepada Tuhan Yang Maha Esa, berakhlak mulia, sehat, berilmu, cakap, kreatif, mandiri, dan menjadi warga negara yang demokratis serta bertanggung jawab.

Teknologi pendidikan merupakan suatu bidang kajian khusus ilmu pendidikan dengan objek formal "belajar". Belajar bukan hanya dilakukan untuk individu melainkan untuk kelompok bahkan, juga diperuntukkan oleh organisasi secara keseluruhan. Dengan adanya teknologi pendidikan, maka kita dapat belajar di mana saja, kapan saja, pada siapa saja, mengenai apa saja, dengan cara dan sumber dari mana saja disesuaikan dengan kondisi dan kebutuhan. Teknologi pendidikan tumbuh dan berkembang dari praktik pendidikan dan gerak komunikasi audiovisual (Heinich dkk, 2011). Teknologi pendidikan semula dilihat sebagai peralatan yang berkaitan dengan penggunaan alat, media dan sarana untuk mencapai tujuan pendidikan atau kegiatan pembelajaran teknologi pendidikan merupakan gabungan dari tiga aliran yang saling berkepentingan yaitu media pendidikan, psikologi pembelajaran, dan pendekatan sistem untuk pendidikan (Rahayu, dkk, 2008).

Masalah yang dialami siswa dalam memahami konsep fisika tidak hanya disebabkan oleh kurangnya pemahaman siswa terhaap suatu konsep, namun bisa juga karena siswa mengalami miskonsepsi. Miskonsepsi yang dialami oleh siswa akan menghambat proses penerimaan pengetahuan baru dalam diri siswa. Selain itu miskonsespsi juga menyebabkan siswa tidak memiliki konsistensi konsepsi (Alfiani, 2015). Menurut Tongchai. A, 2011 dikutip dari jurnal Erika 2020, banyak hasil studi yang menunjukkan bahwa kebanyakan siswa tidak memiliki konsistensi terhadap konsespsi yang dimilikinya, mereka menjawab beberapa pertanyaan secara berbeda satu sama lain terhadap konsespis yang dimilikinya, mereka menjawab beberapa pertanyaan secara berbeda satu sama lain padhal konsep yang sama. Hal ini menunjukkan bahwa siswa tersebut tidak benar-benar memahami suatu konsep. 
Widyastuti (2015) mengungkapkan bahwa ada banyak faktor yang menyebabkan masih rendahnya kemampuan pemahaman konsep siswa. Peninjauan dari berbagai aspek diantaranya: siswa, guru, pendekatan pembelajaran yang diterapkan dan penilaian (assessment), dan kebijakan pemerintah dalam dunia pendidikan. Proses pembelajaran secara biasa dan masih saja berpusat pada guru menjadi penyebab rendahnya pemahaman konsep siswa. Siswa tidak banyak terlibat dalam mengonstruksi pengetahuannya, hanya menerima saja informasi yang disampaikan oleh guru. Siswa menjadi tidak mampu menjawab soal yang berbeda dari contoh yang diberikan guru. Siswa mencontoh dan mengerjakan latihan mengikuti pola yang diberikan guru, bukan dikarenakan siswa memahami konsepnya.

\section{METODE PENELITIAN}

Penelitian merupakan penelitian studi literatur dengan menelaah beberapa jurnal terkait model pembelajaran Sains Teknologi Masyarakat pada materi Gelombang Mekanik.

\section{HASIL DAN PEMBAHASAN}

Dikutip dari jurnal Suarni (2021), berdasarkan observasi awal di SMP Negeri 3 Batukliang kabupaten Lombok Tengah yang dimana proses pembelajaran biologi masih menggunakan metode penugasan dan ceramah, dimana guru hanya menyampaikan materi dengan menulis dipapan tulis dan membaca materi yang akan disampaikan hingga membuat siswa bosan dan jenuh, siswa hanya mendengarkan dan menerima apa yang disampaikan oleh gurunya yang dimana siswa jarang memecahkan masalah. Karena pada kenyataannya pembelajaran biologi harus disertai dengan praktik atau memecahkan masalah. Hal ini menyebabkan siswa mendapatkan hasil pembelajaran yang rendah atau dibawah KKM yaitu 65. Dari alasan tersebut, maka peneliti memberikan alternatif yaitu menerapkan model pembelajaraan sains teknologi masyarakat (STM).Dalam penerapan model pembelajaran sains teknologi masyarakat (STM) siswa dapat terjun langsung dalam melakukan praktik atau memecahkan masalah yang sesuai dengan materi yang diajarkan.. 
Model pembelajaraan sains teknologi ini adalah model pembelajaraan yang mengkaitkan dengan kehidupan sehari-hari atau yang ada dilingkungan sekitar dan juga bagus diterapkan untuk pelajaran-pelajaran yang memecahkan masalah yang berkaitan dengan kehidupan sehari-hari, dimana saat proses tersebut siswa lebih mengerti fungsi dari apa yang guru tugaskan, khususnya pada pelajaran biologi. Pada dasarnya pembelajaran biologi harus diimbangi dengan praktik atau pemacahan masalah agar siswa dapat mengkaitkan materi yang diajarkan oleh gurunya dengan kehipan seharihari.Model ini juga sangat berdampak pada hasil belajar siswa (Suarni, 2021).

Dikutip dari Suarni (2021), untuk menerapkan model pembelajaraan sains teknologi masyarakat (STM) adapun langkah-langkah yang harus dilakukan untuk meningkatkan hasil belajar siswa yakni sebagai berikut: a) Guru menjelaskan materi pokok dan manfaat praktis yang akan diperoleh siswa. b) mengalih isu atau masalah lebih dahulu dari siswa. c) siswa mengahubungkan pembelajaran baru dengan pembelajaraan sebelumnya. d) mengidentifikasi isu atau masalah dalam masyarakat yang berkaitan dengan topik yang dibahas. e) Guru merumuskan pertanyaan- pertanyaan spesifik terhadap isu sains dengan metode Tanya jawab menggungkapkan kembali secara singkant untuk melihat tingkat pemahaman para siswa guru dapat mengiringi pertanyaan para siswa agar siswa yang ditunjuk dapat menjawab pertanyaa. f) Siswa secara berkelompok mencoba merumuskan solusi-solusi alternatif dari isu-isu yang telah dirumuskan.

Setelah penerapan model pembelajaraan sains teknologi masyarakat siswa kembali di berikan test (post-test) untuk mengetahui peningkatan hasil belajar siswa. Hambatan yang dialami dalam menerapkan model pembelajaraan sains teknologi masyarakat (STM) yakni kurangnya minat serta motivasi siswa dalam proses pembelajaraan sehingga membuat cenderung bermalas-malasan. Ditambah hasil yang diperoleh dalam penelitian ini mengungkapkan kebenaran pendapat yang diungkapkan oleh para ahli yang menyatakan bahwa model atau metode pembelajaran dapat dijadikan pola pilihan artinya para guru boleh memilih model dan metode pembelajaran yang sesuai dan efisien untuk mencapai tujuan pembelajarannya (Suarni 2021).

Adapun kelebihan dalam menggunakan atau menerapkan model pembelajaran sains teknologi masyarakat (STM); a) Meningkatkan literasi sains para siswa, 
meningkatkan perhatian siswa terhadap sains dan teknologi serta perhatian terhadap interaksi antara sains, teknologi dan masyarakat. b) Pemahaman yang lebih baik dalam sains. c) Meningkatkan kemampuan berpikir kritis, bernalar logis, memecahkan masalah secara kreatif. d) Peningkatan kemampuan membuat keputusan terhadap permasalahan yang menyangkut sains, teknologi, dan masyarakat. Terlihat jelas dengan menggunakan atau menerapkan model ini sangat berpengaruh dalam proses belajar siswa bersemangat dalam menerima materi yang diajarkan gurunya. Adapun keunikan atau keunggulan model pembelajaraan sains teknologi masyarakat (STM) menurut (Sayuti 2005) antara lain: a) Siswa bersifat aktif dan kreatif dalam proses pembelajaran. b) Kemampuan pemahaman siswa yang tinggi dan rendah akan meningkat. c) Meningkatkan hasil belajar tanpa tambahan waktu dan peralatan atau bahan yang mahal. d) Meningkatnya perhatian Siswa dan kemampuan mengaplikasi dalam kehidupan (Suarni 2021).

Penelitian ini relevan dengan penelitian yang dilakukan oleh Ferdy Novrizal (2010) tentang pengaruh model pembelajaraan sains teknologi masyarakat (STM) terhadap peningkatan penguasaan konsep fisika pada usaha dan energi di SMP Negeri 48 Jakarta Selatan. Hal ini dibuktikan dengan nilai rata-rata $68,34 \%$ dan $62,42 \%$. Jadi didapatkan bahwa dengan menggunakan model (STM) dalam pembelajaraan dapat meningkatkan nilai belajar siswa (Uci Minasari, 2017). Yang artinya siswa di kelas eksperimen dan kelas kontrol pada materi ekosistem ini memiliki pemahaman konsep yang tidak sama atau memiliki perbedaan yang signifikan setelah diberi perlakuan dengan menerapkan model pembelajaraan sains teknologi masyaratak (STM). Hal ini di buktikan dari skor persentasi nilai rata-rata sebesar $80,47 \%$ dan 50,22\%. Dari data diatas yang menunjukan bahwa ada peningkatan hasil belajar siswa setelah menggunakan model pembelajaraan sains teknologi masyarakat (STM) dan dapat diterapkan dalam mata pelajaraan biologi yang merupakan mata pelajaraan yang mengkaitkan materi dengan masalah yang ada dikehidupan sehari-hari.

\section{PENUTUP}

\section{a. Kesimpulan}


Berdasarkan hasil penelitian sebelumnya, terdapat pengaruh model pembelajaran sains teknologimasyarakat (STM) terhadap hasil belajar siswa. Hal ini dapat dilihat dari jurnal Suarni (2021), bahwa nilai thitung lebih besar dari tabel. Maka dari itu penggunaan model pembelajaran sains teknologi masyarakat (STM) ini sangat baik untuk digunakan dalam proses pembelajaran fisika terutama pada materi gelombang mekanik.

\section{b. Saran}

Adapun beberapa saran yang dapat diajukan, saran tersebut adalah sebagai berikut:

1. Bagi guru

Penerapan model pembelajaran peserta didik akan lebih baik jika sesuai dengan karakteristrik peserta didiknya dan juga memperhatikan kurikulum yang berlaku. Agar peserta didik dapat mengikuti pembelajaran dengan baik dan lebih optimal.

2. Bagi peserta didik

Pada proses pembelajaran, peserta didik diharapkan untuk mengikuti secara aktif untuk mengembangkan kemampuan dari diri masing-masing. Jika pembelajaran terlaksana dengan baik, dengan peserta didik yang aktif, maka tujuan pembelajaran akan tercapai sebagaiamana mestinya. 


\section{DAFTAR PUSTAKA}

Alfiani. (2015). Analisis Profil Miskonsepsi dan Konsistensi Konsepsi Siswa SMA pada Topik Suhu dan Kalor. (Prosiding Seminar Nasional Fisika SNF 2015) vol IV

Heinich, R., \& Heinich, R. (2011). Instructional media and technologies for Learning. Englewood Cliffs, N.J: Merrill.

Kurniawan, E. (2012). Perbedaan Metode Brain Based Learning terhadap Capaian Prestasi Prestasi Akademik dan Retensi Pengetahuan Siswa pada Pembelajaran Fisika di Sekolah Menengah Pertama. Skripsi. Universitas Islam Negeri Sunan Kalijaga.

Novrizal, Ferdy. (2010). Pengaruh Model Pembelajaraan Sains Teknologi Masyarakat (STM) Terhadap Peningkatan Penguasaan Konsep Fisika Pada Usaha Dan Energi Kuasai Eksperimen Jakarta Selatan.

Rahayu, Diyah, dkk. (2008). Membedakan Pengertian Teknologi Pendidikan Dengan Teknologi Pembelajaran. Jakarta: UIJ.

Rakhmatika, Erika. (2020). Konsistensi Konsepsi Siswa Melalui Penerapan Model POE2WE pada Materi Gelombang Mekanik. Tasikmalaya: Universitas Siliwangi

Suarni, Rizka, Zinnuarain. (2021). Analisis Pengaruh Penerapan Model Pembelajaran Sains Teknologi Masyarakat Terhadap Hasil Belajar Siswa. Jurnal Paedagogy: Vol. 8 No. 1

Tongchai A. (2011). Consistency of Students' Conceptions of Wave Propagation: Findings from a Conceptual Survey in Mechanical Waves. (Phys. Rev. ST Phys. Educ. Res) vol 7 iss 2 pp 111

Uci Minasari. (2017). Pengaruh Model Pembelajaran Sains Teknologi Masyarakat (STM) Terhadap Kemampuan Pemahaman Konsep Siswa Pada Pokok Pembahasan Ekosistem MTs Paradigma Palembang

Widyastuti, E. 2015. Peningkatan kemampuan pemahaman konsep dan komunikasi siswa dengan menggunakan pembelajaran kooperatif jigsaw. Journal of Mathematics Education, 1(1), 1-14. Terdapat pada http://jurnalnasional.ump.ac.id/. 